\title{
Lama Merokok dan Jumlah Konsumsi Rokok terhadap Trombosit pada Laki-laki Perokok Aktif
}

\section{Smoking Period and Number of Cigarette Consumption with Thrombocyte among Active Male Smokers}

\author{
Rini Sundari, Dinyar Supiadi Widjaya, Aditia Nugraha
} Program Studi Pendidikan Dokter Laboratorium Patologi Klinik Fakultas Kedokteran Universitas Jenderal
Achmad Yani Cimahi

\begin{abstract}
Abstrak
Jumlah perokok dan jumlah rokok yang dikonsumsi mengalami peningkatan dari waktu ke waktu. Rokok dapat memengaruhi trombosit yang dapat menyebabkan gangguan kardiovaskular. Penelitian ini merupakan penelitian potong lintang yang bertujuan untuk menganalisis lama merokok dan jumlah rokok yang dikonsumsi terhadap jumlah trombosit, mean platelet volume (MPV), platelet distribution width (PDW), platelet crit (PCT), dan platelet large cell ratio (PLCR). Penelitian dilakukan di Pabrik Garmen Cimahi pada tahun 2014 yang diikuti oleh 31 laki-laki perokok aktif berusia $19-50(32,97 \pm 10,28)$ tahun, $70,9 \%$ di antaranya sebagai perokok sedang. Analisis data dilakukan secara deskriptif, uji normalitas Shapiro-Wilk, dan uji korelasi Spearman's rho. Peserta telah merokok selama minimal dan maksimal dengan rata-rata $( \pm \mathrm{SB})$, yaitu 3 - 25 tahun $(10,48 \pm 6,33)$ dan konsumsi rokok sebanyak 5 - 25 batang per hari $(13,10 \pm 4,99)$. Jumlah trombosit $171-422(280,9 \pm 56,2) \times 10^{\wedge} 3 \mathrm{sel} / \mathrm{mm}^{3}$, MPV 8,8 - 13,6 $(10,14 \pm 0,93)$ fL, PDW 8,7 - 13,8 (10,27 + 1,22) fL, PLCR 14,4 - 38,8\% (24,91 $\pm 5,46)$, dan PCT 0,1 - 0,4\%(0,28 $\pm 0,06)$. Sebaran ukuran trombosit ditemukan normal, namun dengan ukuran besar sesuai nilai MPV dan PLCR yang tinggi. PCT normal berkorelasi sangat kuat dengan jumlah trombosit. Jumlah batang rokok yang dikonsumsi berkorelasi lemah dengan lamanya merokok. Lama merokok dan jumlah rokok yang dikonsumsi berkorelasi negatif dengan jumlah trombosit, MPV, PDW maupun PLCR.

Kata kunci: Jumlah konsumsi rokok, lama merokok, parameter trombosit
\end{abstract}

\section{Abstract}

Number of smokers and cigarette consumption are increasing from time to time. Cigarettes influence thrombocytes which may cause cardiovascular disorder. This study was a cross sectional study aiming to analyze smoking period and cigarette consumption number toward the number of thrombocytes, MPV, PDW, PCT and PLCR. This study was conducted at Cimahi Garment Factory in 2014 participated by 31 active male smokers in age of 19 - $50(32,97 \pm 10,28)$ years old in which $70,9 \%$ of them were medium smokers. Data analysis was conducted descriptively, using Shapiro-Wilk normality test and Spearman's rho correlation test. Participants had been smoking for the minimum and maximum $3-25(10.48 \pm 6.33)$ years and 5 $25(13.10 \pm 4.99)$ cigarettes in average per day. The number of thrombocytes was worth $171-422(280,9 \pm 56,2) \times 10^{\wedge} 3 \mathrm{cells} / \mathrm{mm}^{3}$, MPV $8.8-13.6$ $(10.14 \pm 0.93) \mathrm{fL}$, PDW $8.7-13.8(10.27 \pm 1.22) \mathrm{fL}, \mathrm{PLCR} 14.4-38.8 \%$ $(24.91 \pm 5.46)$ and PCT $0.1-0.4 \%(0.28 \pm 0.06)$. PDW was found normal with the giant shape in accordance with the high MPV and PLCR value. PCT was normal correlated strongly with thrombocyte number. The cigarette consumption number had a weak correlation with the smoking period. The smoking period and the cigarette consumption number had a negative correlation with the number of thrombocytes, MPV, PDW and PLCR.

Keywords: Smoking period, number of cigarette consumption, thrombocyte parameter

\section{Pendahuluan}

Jumlah perokok dari waktu ke waktu mengalami peningkatan, baik perempuan maupun laki-laki, meskipun jumlah perokok masih tetap lebih banyak ditemukan pada laki-laki. Usia perokok juga semakin bervariasi, banyak perokok mulai merokok pada usia anak-anak bahkan ditemukan pada usia 11 bulan. ${ }^{1,2}$ Meskipun regulasi pengendalian masalah merokok di Indonesia telah dikeluarkan, baik dalam bentuk peraturan perundangundangan yang dihasilkan oleh badan legislatif maupun peraturan yang dikeluarkan oleh badan eksekutif, jumlah perokok di Indonesia tetap tinggi bahkan menempati urutan ketiga di dunia setelah Tiongkok dan India.,

Korespondensi: Rini Sundari, Laboratorium Patologi Klinik FK Universitas Jend Achmad Yani Cimahi, Jl. Terusan Jendral Sudirman Cimahi Jawa Barat 14857, No.Telp: 022-6642781, e-mail: rinihw@yahoo.com 
Tingginya jumlah perokok tersebut dapat diakibatkan karena rokok menyebabkan kecanduan miopik. ${ }^{4}$ Prevalensi perokok usia di atas 15 tahun di Indonesia pada tahun 2010 mencapai 34,7\%. Bahkan menurut Dhae, hingga saat ini, terdapat $69 \%$ remaja di Indonesia menjadi perokok aktif.1,2 Jumlah perokok lebih sedikit dilaporkan pada mahasiswa angkatan 2011 Fakultas Kedokteran Universitas Gadjah Mada Yogyakarta, yaitu pernah merokok sebanyak $11,89 \%$ dan masih merokok 3,1\%..$^{5}$ Pada tahun 2012, di Indonesia diperkirakan lebih dari $40 \%$ laki-laki dan kurang dari $5 \%$ perempuan merokok. ${ }^{6}$ Prevalensi perokok di Jawa Barat pada laki-laki sebesar 30,9\% dan perempuan sebesar 6,8\%, angka ini cenderung meningkat dari waktu ke waktu. ${ }^{2}$

Seseorang dikategorikan sebagai perokok aktif apabila merokok setiap hari dalam jangka waktu minimal enam bulan selama hidupnya dan masih merokok pada saat dilakukan penelitian. Perokok menurut World Health Organization (WHO) diklasifikasikan menjadi tiga kelompok berdasarkan jumlah rokok yang dihisap per hari, yaitu seseorang yang mengonsumsi rokok satu sampai sepuluh batang per hari disebut perokok ringan, 11 - 20 batang per hari disebut perokok sedang, dan lebih dari 20 batang per hari disebut perokok berat. ${ }^{7}$

Rokok diketahui sebagai faktor risiko terjadinya aterosklerosis dan gangguan kardiovaskular. Pengaruh rokok pada trombosit dapat menyebabkan peningkatan aterosklerosis dan menjadi faktor risiko penyakit aterosklerotik akibat peningkatan mean platelet volume (MPV). ${ }^{8,9}$ Rokok mengandung ribuan bahan kimia beracun yang berdampak buruk pada kesehatan, di antaranya tar, nikotin, timah hitam, dan karbon monoksida. Kandungan zat berbahaya dalam rokok tersebut dapat memengaruhi trombosit. Rokok dapat menyebabkan berkurangnya glutation pada trombosit perokok sehingga terjadi penurunan isoprostan pada trombosit. Aktivitas isoprostan secara langsung berinteraksi dengan thromboxane- $A_{2}$ receptor (TPR) pada trombosit menunjukkan peningkatan risiko terjadi penyakit vaskular. ${ }^{10,11}$

MPV merupakan indikator terjadinya aktivasi trombosit. Yarlioglues, ${ }^{9}$ melaporkan bahwa semakin tinggi pajanan karbon monoksida akan semakin meningkatkan MPV. Ljunberg, ${ }^{12}$ melaporkan hal yang berbeda bahwa ekstrak tembakau mempunyai efek penghambat pada adesi trombosit yang independen dengan kandungan nikotin dan jalur nitric-oxide-pathway yang tidak dimediasi melalui platelet-nicotine-receptor. Ekstrak tembakau menghambat aktivasi trombosit dalam jangka waktu yang pendek. Perempuan tidak merokok tetapi terpajan rokok selama minimal 60 menit per hari selama 30 tahun atau lebih dalam hidupnya berisiko mempunyai MPV rendah. ${ }^{13}$ Selain itu, rokok juga diketahui meningkatkan agregasi trombosit karena zat kimia dalam asap rokok yang terinhalasi akan merangsang trombok- san $\mathrm{A}_{2}$. Tromboksan $\mathrm{A}_{2}$ akan mengaktifkan produksi trombosit. ${ }^{14}$ Penelitian lain dilakukan antara laki-laki perokok dan perempuan perokok, dilaporkan bahwa trombosit pada laki-laki perokok kurang sensitif dibandingkan pada perempuan karena trombosit pada laki-laki kurang sensitif terhadap metabolit tembakau. ${ }^{15}$

Berdasarkan hal tersebut, maka dilakukan penelitian mengenai korelasi lama merokok dan jumlah rokok yang dikonsumsi per hari dengan trombosit pada laki-laki perokok aktif. Adapun parameter trombosit yang dimaksud dalam penelitian ini meliputi jumlah trombosit, MPV, platelet distribution width (PDW), platelet crit (PCT), dan platelet large cell ratio (PLCR). ${ }^{16}$ Penelitian ini bertujuan untuk menganalisis lama merokok dengan jumlah trombosit, MPV, PDW, PCT, dan PLCR serta menganalisis korelasi jumlah rokok yang dikonsumsi dengan jumlah trombosit, MPV, PDW, PCT, dan PLCR.

\section{Metode}

Penelitian ini merupakan penelitian potong lintang yang dilakukan pada Januari - Mei 2014. Sampel peserta penelitian dilakukan secara total sampling yang diikuti oleh 31 laki-laki perokok aktif di Pabrik Garmen Cimahi. Pengambilan darah dilakukan pada jam istirahat dan pemeriksaan trombosit dilakukan segera sebelum dua jam dari waktu pengambilan darah. Penelitian ini merupakan bagian dari penelitian pendahuluan tentang hemostasis pada perokok aktif dan perokok pasif, meliputi parameter trombosit, faktor koagulasi, dan agregasi trombosit. Peserta yang mengikuti penelitian ini adalah peserta yang merokok setiap hari dan telah merokok minimal enam bulan. Peserta juga tidak sedang mengonsumsi obat antiplatelet, mempunyai riwayat transfusi darah selama dua minggu sebelum penelitian, atau memiliki riwayat gangguan perdarahan. Selain itu, peserta tidak menderita diabetes melitus, hipertensi, anemia, demam berdarah, atau demam tifoid. Kesediaan mengikuti penelitian ini dibuktikan dengan mengisi lembar persetujuan setelah mendapatkan penjelasan dari peneliti.

Pemeriksaan trombosit menggunakan darah ethylen diamine tetracetic acid (EDTA) yang dilakukan dengan hematoanalyzer Sysmex XS-800i di Laboratorium Patologi Klinik Fakultas Kedokteran Universitas Jenderal Achmad Yani Cimahi, Jawa Barat. Pemeriksaan trombosit meliputi jumlah trombosit, MPV, PDW, PCT, dan PLCR. Data dianalisis secara deskriptif untuk menilai rentang, median, rata-rata, dan simpang baku dari masing-masing variabel. Untuk mengetahui korelasi antara lama merokok dan jumlah batang rokok yang dikonsumsi dengan masing-masing parameter trombosit, dilakukan uji korelasi Pearson atau Spearman's rho. Sebelum analisis korelasi, dilakukan uji normalitas data dengan analisis Shapiro-Wilk. Analisis data dengan distribusi normal dilakukan uji korelasi Pearson, sedangkan data dengan 
distribusi tidak normal dilakukan analisis Spearman's rho dengan uji kemaknaan 95\%.

\section{Hasil}

Penelitian dilakukan di Cimahi, diikuti oleh 31 laki-laki perokok aktif. Seluruh peserta merupakan pekerja di pabrik yang telah menerapkan aturan larangan merokok selama bekerja. Peserta termuda berusia 19 tahun dan tertua berusia 50 tahun dengan rata-rata usia 33 tahun dengan simpang baku 10,3 tahun. Merokok terbanyak dimulai pada usia 20 tahun, usia termuda mulai merokok adalah 14 tahun. Peserta telah merokok selama tiga hingga 25 tahun $(10,48 \pm 6,33$ tahun) dan merokok sebanyak lima sampai 25 batang rokok per hari $(13,10 \pm 4,99$ batang rokok). Jumlah rokok yang dikonsumsi oleh lakilaki perokok berkorelasi dengan lamanya merokok seperti tampak pada Gambar 1.

Sebanyak 27 laki-laki perokok $(87,1 \%)$ memiliki jumlah trombosit normal dan tidak seorang pun trombositopenia. Hasil pemeriksaan menunjukkan jumlah trombosit $172-422 \times 10^{\wedge} 3 \mathrm{sel} / \mathrm{mm}^{3}$. MPV yang menggambarkan ukuran trombosit ditemukan normal pada 15 perokok $(48,4 \%)$ dan sisanya sebanyak 51,6\% perokok ditemukan MPV meningkat. Adapun hasil pemeriksaan MPV pada laki-laki perokok aktif, yaitu 8,813,6 fL. Pada laki-laki perokok aktif diperoleh hasil pemeriksaan PDW sebesar 8,7 - 13,8 fL, lima perokok di antaranya memiliki PDW yang rendah dan $83,9 \%$ PDW normal. Semua laki-laki perokok aktif dalam penelitian ini mempunyai nilai PCT normal, yaitu 0,1 - 0,4\% Semua perokok mempunyai rasio ukuran trombosit besar yang digambarkan melalui PLCR sebesar 14,4 $38,8 \%$. Data selengkapnya disajikan pada Tabel 1 .

Jumlah rokok yang dikonsumsi memiliki korelasi negatif dengan semua parameter trombosit, yaitu jumlah trombosit $(\mathrm{r}=-0,286)$, PCT $(\mathrm{r}=-0,343)$, PDW $(\mathrm{r}=-$ $0,080)$, MPV $(r=-0,038)$, dan PLCR $(r=-0,038)$. Demikian pula, korelasi lama merokok dengan jumlah trombosit, PCT, PDW, MPV, dan PLCR (Gambar 2 dan Gambar 3).

\section{Pembahasan}

Penelitian ini menemukan bahwa usia merokok dimulai sejak usia 14 tahun. Usia ini jauh lebih muda apabila dibandingkan dengan rata-rata usia mulai merokok, baik yang dilaporkan oleh Hidayat, ${ }^{4}$ 20,8 tahun maupun secara nasional (17,6 tahun). ${ }^{1}$ Pada penelitian ini, peserta telah merokok selama tiga hingga 25 tahun dengan rata-rata 10,48 $\pm 6,33$ tahun. Jumlah rokok yang dikonsumsi setiap harinya berkisar antara lima sampai 25 batang rokok. Sebanyak 70,9\% di antaranya sebagai perokok sedang, yaitu mengonsumsi rokok sebanyak 11 - 20 batang rokok per hari, sedangkan perokok berat sebanyak dua orang $(6,4 \%)$, dan $22,6 \%$ sebagai perokok

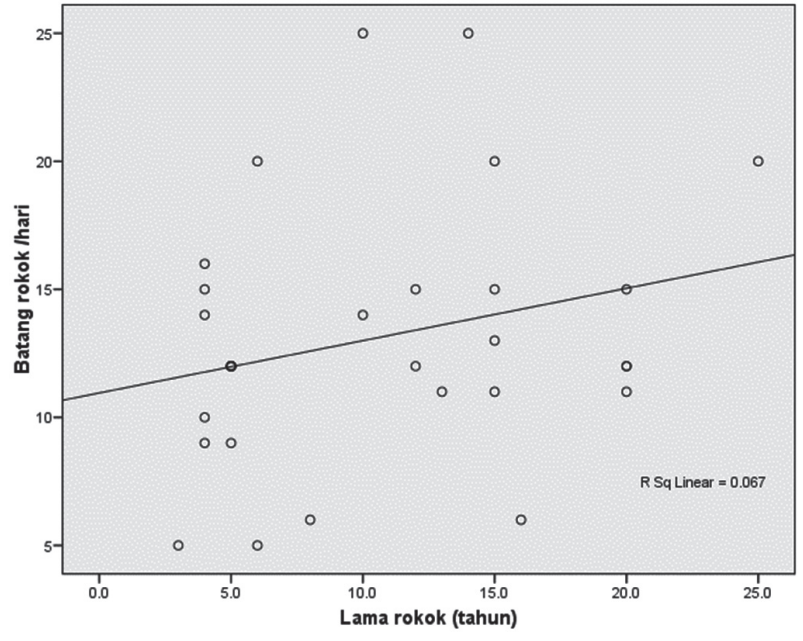

Gambar 1. Korelasi antara Jumlah Batang Rokok yang Dikonsumsi per Hari dengan Lama Merokok

Tabel 1. Hasil Pemeriksaan Jumlah Trombosit, MPV, PDW, PCT, dan PLCR pada Laki-laki Perokok Aktif

\begin{tabular}{lccccc}
\hline Parameter & Minimal & Maksimal & Median & Rata-rata & SD \\
\hline $\begin{array}{l}\text { Jumlah trombosit } \\
\left(\times 10^{3} \mathrm{sel} / \mathrm{mm}^{3}\right)\end{array}$ & 172 & 422 & 278 & 280,9 & 56,2 \\
MPV (fL) & 8,8 & 13,6 & 10,10 & 10,14 & 0,93 \\
PDW (fL) & 8,7 & 13,8 & 11,40 & 11,27 & 1,22 \\
PCT (\%) & 0,1 & 0,4 & 0,27 & 0,28 & 0,06 \\
PLCR (\%) & 14,4 & 38,8 & 24,90 & 24,91 & 5,46 \\
\hline
\end{tabular}

ringan. Hasil ini sesuai dengan yang dilaporkan oleh $\mathrm{Ng}$ dkk., 6 bahwa perokok di Indonesia termasuk dalam perokok kelas medium (sedang). Jumlah rokok yang dikonsumsi ini berkorelasi rendah dengan lama merokok $(\mathrm{r}=$ 0,219 ; nilai $\mathrm{p}=0,237$ ), semakin lama merokok semakin banyak rokok yang dikonsumsi (Gambar 1). Namun demikian, karena memiliki korelasi yang rendah, dapat diartikan pula bahwa seseorang yang baru merokok bukan berarti akan mengonsumsi jumlah rokok yang lebih sedikit, atau sebaliknya yang sudah merokok lama akan mengonsumsi rokok yang lebih banyak pula.

Parameter penting pada pemeriksaan trombosit meliputi jumlah trombosit, MPV, PDW, PCT, dan PLCR. MPV menggambarkan ukuran trombosit, PDW menunjukkan deviasi rasio volume atau ukuran trombosit pada histogram, PCT menunjukkan rasio volume total trombosit pada histogram terhadap volume darah yang diaspirasi, dan PLCR menunjukkan rasio ukuran trombosit besar. ${ }^{16-19}$ Dalam praktik sehari-hari, yang digunakan untuk analisis keadaan pasien hanya jumlah trombosit, sedangkan parameter lainnya (MPV, PDW, PCT, dan PLCR) masih jarang digunakan dalam analisis keadaan pasien.

Nilai rujukan jumlah trombosit berbeda-beda antara lain adanya variasi diurnal lebih tinggi sekitar 5\%, jenis kelamin perempuan $20 \%$ lebih tinggi dibandingkan laki- 

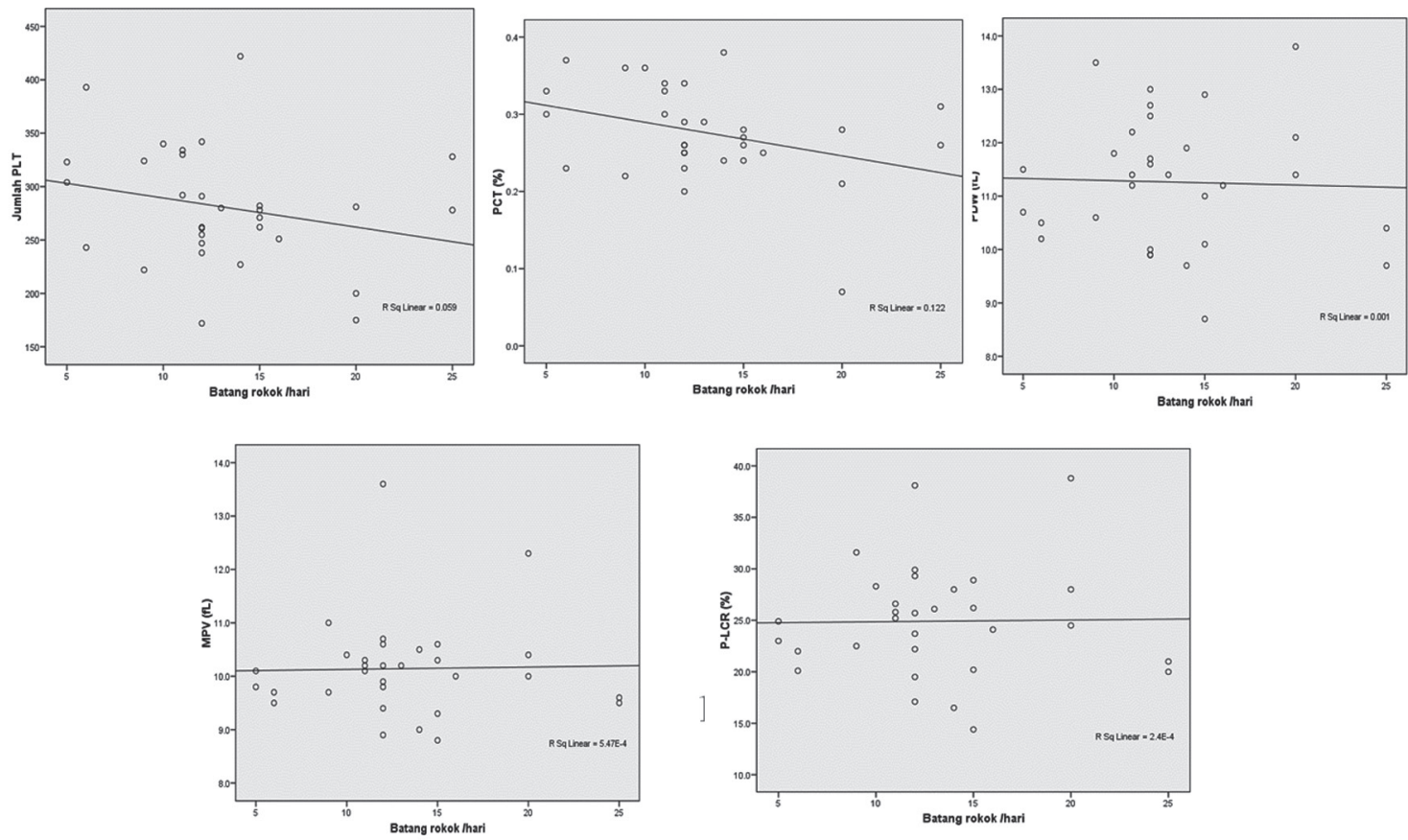

Gambar 2. Korelasi antara Jumlah Rokok yang Dikonsumsi dengan Jumlah Trombosit, PCT, PDW, MPV, dan PLCR pada Laki-laki Perokok Aktif
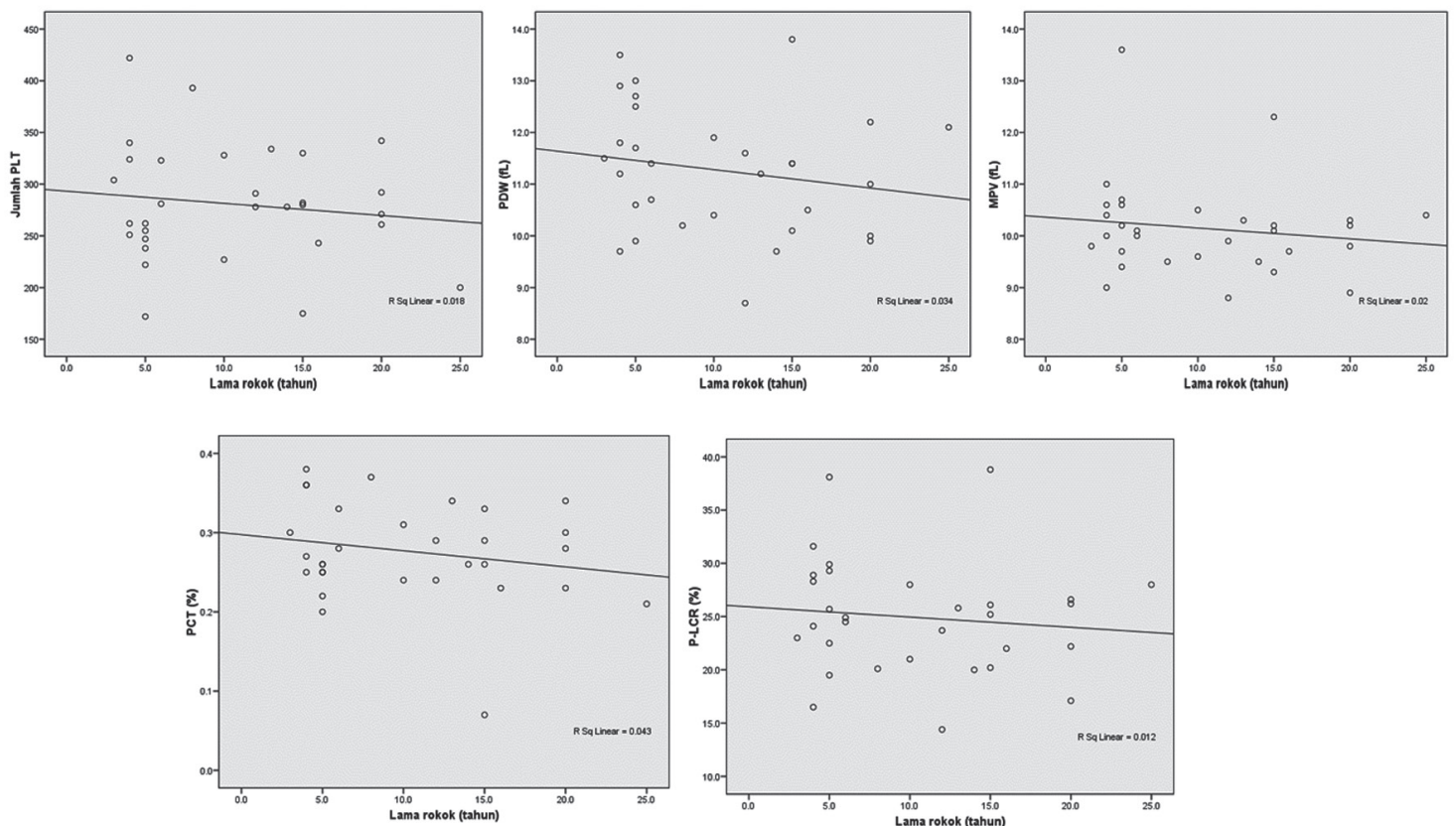

Gambar 3. Korelasi antara Lama Merokok dengan Jumlah Trombosit, PCT, PDW, MPV, dan PLCR pada Laki-laki Perokok Aktif

laki, dan perbedaan etnis. Etnis West Indian dan Afrika memiliki jumlah trombosit $10-20 \%$ lebih rendah dibandingkan orang Eropa yang tinggal pada lingkungan yang sama. ${ }^{20}$ Nilai rujukan jumlah trombosit (dalam $\mathrm{x} 10^{3} \mathrm{sel} / \mathrm{mm}^{3}$ ) menurut Perhimpunan Dokter Spesialis Patologi Klinik Indonesia, ${ }^{21}$ pada laki-laki usia 16 - 20 tahun sebanyak 140 - 392, Sysmex, ${ }^{16}$ nilai rujukan untuk laki-laki sebanyak 163 - 337, Nihon Kohden, ${ }^{18}$ sebanyak
120 - 180 dan Bates et al., 20 sebanyak 150 - 410, dengan tingkat kepercayaan $95 \%$.

Pada penelitian ini, pengambilan darah dilakukan pada jam istirahat siang karyawan. Pengambilan sampel pada waktu yang sama bertujuan untuk meminimalkan adanya variasi diurnal di antara peserta. ${ }^{20}$ Berdasarkan hasil pada Tabel 1, tampak bahwa tidak ditemukan trombositopenia. Apabila didasarkan pada nilai rujukan dari 
Perhimpunan Dosen Spesialis Patologi Klinik, maka terdapat dua $(6,4 \%)$ laki-laki perokok aktif yang mengalami trombositosis. Namun, karena pemeriksaan trombosit pada penelitian ini menggunakan hematology analyzer, trombositosis ditemukan pada empat $(12,8 \%)$ laki-laki perokok aktif. Jumlah trombosit secara transien dipengaruhi oleh rokok. ${ }^{20}$ Butkiewicz, ${ }^{15}$ melaporkan jumlah trombosit pada laki-laki perokok sebanyak $237 \pm 39,52$ $\mathrm{x} 10^{\wedge 3} \mathrm{sel} / \mathrm{mm}^{3}$. Demikian pula Al-Dahr, ${ }^{22}$ melaporkan jumlah trombosit pada perokok sigaret dan shisha juga masih dalam batas normal, yaitu 264,2 \pm 64,3 dan $306 \pm$ $79,7 \times 10^{\wedge 3} \mathrm{sel} / \mathrm{mm}^{3}$. Sedangkan penelitian pada tikus yang dipapar rokok mempunyai jumlah trombosit lebih rendah tidak bermakna (nilai $\mathrm{p}=0,13$ ) dibandingkan kelompok kontrol. ${ }^{23}$ Trombosit pada perokok kurang sensitif terhadap prostasiklin eksogen sehingga akan berpengaruh pada usia dan fungsi trombosit. Zat kimia pada asap rokok yang telah terinhalasi dalam tubuh akan merangsang tromboksan $\mathrm{A}_{2}$ dalam darah yang berperan mengaktifkan produksi trombosit yang baru dan meningkatkan agregasi trombosit. Agregasi trombosit dapat kembali normal apabila terdapat prostasiklin di dalam darah, yang akan menghambat agregasi trombosit dan menjaganya tetap stabil. ${ }^{14}$

MPV berasal dari penghitungan rasio antara PCT (\%) dan jumlah trombosit dikalikan 10.000 .18 Pada Tabel 1, MPV laki-laki perokok aktif berkisar 8,8-13,6 $\mathrm{fL}(10,14 \pm 0,93)$. Trombosit normal dalam sirkulasi mempunyai diameter 2 - 5 milimeter, tebal 0,5 milimeter, dan volume rata-rata (MPV) $6-10$ fL. ${ }^{24} \mathrm{Al}-\mathrm{Dahr},{ }^{22}$ melaporkan nilai MPV pada perokok kretek 8,2 $\pm 1,0 \mathrm{fL}$, perokok shisha 8,3 $\pm 0,9 \mathrm{fL}$, dan kelompok kontrol 8,4 $\pm 0,8 \mathrm{fL}$.

Berdasarkan rata-rata MPV pada Tabel 1, tampak bahwa nilai MPV laki-laki perokok aktif memiliki trombosit berukuran besar, bahkan sebanyak $16(51,6 \%)$ peserta memiliki ukuran lebih dari $10 \mathrm{fL}$. Hal ini terjadi karena rokok dapat menyebabkan aktivasi trombosit sehingga terjadi agregasi akibat meningkatnya tromboksan $\mathrm{A}_{2} \cdot{ }^{14}$ Aktivasi trombosit ini menyebabkan trombosit berukuran besar yang dikenal dengan giant thrombocyte. Aktivasi trombosit pada perokok tersebut terjadi melalui receptor of AGEs (RAGE)-mediated downstream signaling, atau efek langsung pada dinding pembuluh darah dan matriks protein. 25,26

Peningkatan agregasi trombosit akibat rokok dapat pula disebabkan oleh agregasi $P$-selectin-dependent platelet-leukocyte dan adhesi leukosit pada permukaan vaskular baik secara in vitro dan in vivo. ${ }^{27} \mathrm{MPV}$ yang besar juga disebabkan trombosit pada perokok mempunyai gambaran globular membran trombosit dan pseudopodia permukaan lebih menonjol dibandingkan kelompok kontrol sehingga ukuran trombosit besar. ${ }^{28,29}$ Pada laki-laki perokok aktif, selain ditemukan MPV yang tinggi juga ditemukan sebaran ukuran trombosit yang sempit. PDW pada laki-laki perokok dalam penelitian ini sebesar 11,40 $\pm 1,22 \mathrm{fL}$, dengan sebaran atau variasi ukuran trombosit ini masih dalam rentang normal, bahkan lima peserta mempunyai sebaran yang rendah atau kurang dari $10 \mathrm{fL}$. Hal ini menunjukkan bahwa ukuran trombosit pada lakilaki perokok aktif relatif homogen.

MPV yang tinggi menggambarkan ukuran yang besar, sedangkan persentase ukuran trombosit yang besar digambarkan dengan PLCR yang tinggi pula. Pada Tabel 1 tampak bahwa PLCR pada laki-laki perokok aktif sebesar $14,4-38,8 \%(24,91 \pm 5,46 \%)$. Weinberg melaporkan ukuran trombosit ditemukan lebih besar pada perokok dibandingkan bukan perokok. ${ }^{30} \mathrm{Hal}$ ini berarti hampir seperempat populasi trombosit mempunyai ukuran trombosit yang besar. PLCR yang besar sesuai dengan MPV yang tinggi, bahkan memiliki korelasi yang sangat kuat yang ditunjukkan dengan kekuatan korelasi sebesar 0,991 (Spearman's rho, nilai $\mathrm{p}=0,000$ ). Selain itu, juga dapat diartikan bahwa PLCR ini mempunyai pengaruh (determinan, $\mathrm{r}^{2}$ ) sebesar $98,2 \%$ terhadap ukuran trombosit. Semakin tinggi persentase giant thrombocyte semakin tinggi nilai PLCR. Apabila ditinjau dari PDW masih dalam batas normal, bahkan terdapat 16,1\% peserta memiliki PDW kecil, maka sesuai dengan tingginya MPV atau besarnya PLCR. Hal ini ditunjukkan dengan pengaruh yang sangat besar PDW terhadap MPV dan PLCR. Pengaruh MPV terhadap PDW sebesar $85,2 \%$ (Spearman's rho $\mathrm{r}=0,923 ; \mathrm{p}=0,000$ ), sedangkan terhadap PLCR sebesar 89,1\% (Spearman's rho $\mathrm{r}=$ $0,944$; nilai $\mathrm{p}=0,000)$. PCT pada laki-laki perokok aktif masih ditemukan normal PCT (normal 0,1 - 1,0\%), yaitu $0,1-0,4 \%(0,28 \pm 0,06 \%)$. PCT identik dengan hematokrit pada pemeriksaan hemoglobin, merupakan rasio volume total trombosit pada histogram terhadap volume darah yang diaspirasi. ${ }^{10}$ PCT ini tidak memengaruhi ukuran maupun variasi ukuran trombosit, ditunjukkan dengan korelasi terbalik antara PCT dengan MPV, PDW, dan PLCR secara berturut-turut memiliki korelasi (r) sebesar -0,104, -0,139, dan -0,115. Sedangkan terhadap jumlah trombosit sangat memengaruhi nilai hematokrit, seperti halnya nilai hematokrit sesuai dengan kadar hemoglobin. Jumlah trombosit mempunyai korelasi sangat kuat (Spearman's rho $\mathrm{r}=0,945$; nilai $\mathrm{p}=0,000$ ) atau jumlah trombosit memengaruhi 89,3\% PCT.

Gambar 2 dan Gambar 3 menunjukkan korelasi antara lama merokok dan jumlah rokok yang dikonsumsi dengan lima parameter trombosit pada laki-laki perokok aktif. Berdasarkan analisis Shapiro-Wilk, diperoleh bahwa semua parameter trombosit mempunyai distribusi tidak normal. Terdapat korelasi negatif antara lama merokok dengan jumlah trombosit, MPV, PDW, PLCR, dan PCT. Namun, seluruhnya memiliki korelasi yang tidak bermakna. Demikian pula antara jumlah rokok 
yang dikonsumsi dengan kelima parameter trombosit tersebut. Korelasi yang sangat kuat ditunjukkan di antara parameter trombosit itu sendiri seperti telah disebutkan sebelumnya.

Jumlah trombosit berkorelasi negatif dengan lamanya merokok dan jumlah rokok yang dikonsumsi. Lama merokok akan berpengaruh pada usia trombosit. Usia trombosit dalam sirkulasi sekitar 10 hari, namun dengan menurunnya respons terhadap prostasiklin menyebabkan usia trombosit menurun. ${ }^{24,30}$ Hal tersebut menyebabkan jumlah trombosit menurun sehingga sesuai dengan penelitian ini bahwa semakin lama merokok, jumlah trombosit semakin menurun (Gambar 3). Selain itu, senyawa dalam rokok juga akan menghambat platelet activating factor (PAF). 31

MPV berkorelasi sangat lemah dengan lama merokok $(\mathrm{r}=-0,152)$ dan jumlah rokok yang dikonsumsi $(\mathrm{r}=$ 0,038). Hasil ini tidak sesuai dengan penelitian paparan karbon monoksida yang dilakukan oleh Yarlioglues, et al. ${ }^{9}$ Orang bukan perokok yang dipajan dengan karbon monoksida sebanyak kurang dari 7,5 ppm, 7,5 - 15 ppm, dan lebih dari 15 ppm menunjukkan semakin tinggi kadar karbon monoksida menyebabkan semakin tinggi MPV. Selain itu, lamanya pajanan karbon monoksida juga menyebabkan peningkatan MPV. Penelitian ini memberikan kesan bahwa pajanan akut pada perokok pasif akan berpengaruh pada MPV menurut lama dan intensitas rokok. Trombosit pada perokok aktif kurang sensitif terhadap prostasiklin eksogen tersebut juga akan memengaruhi fungsi trombosit, sehingga trombosit mudah agregasi. ${ }^{24,30}$

Tingginya MPV dan peningkatan aktivitas trombosit ini berkaitan dengan risiko terjadinya hipertensi, infark miokard akut, atau aterosklerosis. ${ }^{19,31}$ Adanya peningkatan agregasi ini sebagai tanda terjadinya peningkatan aktivasi. Karena trombosit mudah agregasi, akan terjadi peningkatan volume trombosit. Peningkatan agregasi trombosit dapat pula disebabkan karena efek langsung nikotin atau karena peningkatan katekolamin plasma. ${ }^{30}$ Dalam keadaan normal, jumlah trombosit kontradiktif dengan MPV. Namun, pada perokok trombosit menjadi besar dikarenakan terjadi peningkatan aktivasi. Penelitian ini tidak menemukan korelasi bermakna antara lama merokok dan jumlah rokok yang dikonsumsi dengan trombosit dalam hal jumlah trombosit, sebaran trombosit, ukuran trombosit, dan rasio ukuran trombosit besar dapat disebabkan beberapa perancu yang belum dapat disingkirkan, antara lain penyakit penyerta dan penggunaan obat yang memengaruhi trombosit. Korelasi yang lemah antara banyaknya rokok yang dikonsumsi setiap hari dan lama merokok dengan lima parameter trombosit dapat disebabkan karena keterbatasan jumlah sampel dalam penelitian ini yang hanya diikuti oleh 31 peserta perokok aktif.

\section{Kesimpulan}

Sebagian besar laki-laki perokok aktif $(87,1 \%)$ memiliki jumlah trombosit normal, 51,6\% memiliki ukuran trombosit yang besar (MPV lebih dari $10 \mathrm{fL}$ ) dengan PLCR sebesar 14,4 - 38,8\%. Sebaran ukuran trombosit ditemukan normal PDW yang berarti pada laki-laki perokok aktif ukuran trombosit homogen, namun homogen besar yang ditunjukkan oleh tingginya nilai MPV dan PLCR. PCT normal berkorelasi sangat kuat dengan jumlah trombosit. Terdapat korelasi lemah antara jumlah rokok yang dikonsumsi dan lamanya merokok dengan parameter trombosit pada laki-laki perokok aktif. Korelasi kuat terjadi di antara parameter trombosit itu sendiri.

\section{Saran}

Berdasarkan hasil yang telah diperoleh dalam penelitian ini, terdapat korelasi lemah antara jumlah rokok yang dikonsumsi dan lamanya merokok dengan parameter trombosit yang disebabkan keterbatasan jumlah sampel, maka perlu dilakukan penelitian lebih lanjut dengan memerhatikan jumlah sampel yang sesuai untuk penelitian korelasi. Selain itu, perlu dilakukan penelitian pada kelompok bukan perokok dan perokok pasif terkait parameter trombosit sehingga dapat pula diketahui apakah hasil pemeriksaan parameter trombosit akibat rokok atau tidak dengan memerhatikan faktor-faktor perancu.

\section{Daftar Pustaka}

1. Departemen Kesehatan Republik Indonesia. Laporan riset kesehatan dasar tahun 2010. Jakarta: Departemen Kesehatan Republik Indonesia; 2010.

2. Dhae A. Remaja dominasi perokok aktif di Indonesia [online]. Jakarta: TCSC Indonesia; 2014 [diakses tanggal 5 Agustus 2014]. Diunduh dari: http://www.tcsc-indonesia.org/remaja-dominasi-perokok-aktif-di-indonesia/.

3. Achadi A. Regulasi pengendalian masalah rokok di Indonesia. Kesmas: Jurnal Kesehatan Masyarakat Nasional. 2008; 2(4): 161-5.

4. Hidayat B, Thabrany H. Model spesifikasi dinamis permintaan rokok: rasionalkah perokok Indonesia? Kesmas: Jurnal Kesehatan Masyarakat Nasional. 2008; 3(3): 99-108.

5. Yudha DN, Prabandari YS, Purwanta. Tingkat pengetahuan dan persepsi terhadap shisha pada mahasiswa. Kesmas: Jurnal Kesehatan Masyarakat Nasional. 2014; 9(1): 19-26.

6. Ng M, Freeman MK, Fleming TD, Robinson M, Dwyer-Lindgren L, Thomson B, et al. Smoking prevalence and cigarette consumption in 187 countries, 1980-2012. Journal of the American Medical Association. 2014 Jan 8; 311(2):183-92.

7. Departemen Kesehatan Republik Indonesia. Konsumsi Rokok dan Prevalensi Merokok. Jakarta: Departemen Kesehatan Republik Indonesia; 2004.

8. Padmavathi P, Reddy V, Maturu P, Varadacharyulu N. Smoking-induced alterations in platelet membrane fluidity and $\mathrm{Na}(+) \mathrm{K}(+)$-ATPase activity in chronic cigarette smokers. Journal of Atherosclerosis and 
Thrombosis. 2010; 17(6): 619-27.

9. Yarlioglues M, Ardic I, Dogdu O, Akpek M, Zencir C, Kasapkara HA, et al. The acute effects of passive smoking on mean platelet volume in healthy volunteers. Angiology. 2012 Jul; 63(5): 353-7.

10. Laffan M, Manning R. Investigation of haemostasis. In: Bain B, Bates I, Laffan M, Lewis S, editors. Dacie and Lewis practical haematology. $11^{\text {th }}$ ed. London Philadelphia Toronto: Churchil Livingstone; 2012. p. 393-445.

11. Ting HJ, Khasawneh FT. Platelet function and isoprostane biology. Should isoprostanes be the newest member of the orphan-ligand family? Journal of Biomedical Science. 2010; 17(1): 24.

12. Ljungberg LU, Persson K, Eriksson AC, Green H, Whiss PA. Effects of nicotine, its metabolites and tobacco extracts on human platelet function in vitro. Toxicol In Vitro. 2013 Mar; 27(2): 932-8.

13. Liu C, Yang Y, He M, Yao P, Chen W, Liang Y. Passive smoke exposure was related to mean platelet volume in never-smokers. American Journal of Health Behavior. 2014 Jul; 38(4): 519-28.

14. Hioki H, Aoki N, Kawano K, Homori M, Hasumura Y, Yasumura T, et al. Acute effects of cigarette smoking on platelet-dependent thrombin generation. European Heart Journal. 2001 Jan; 22(1): 56-61.

15. Butkiewicz AM, Kemona-Chetnik I, Dymicka-Piekarska V, MatowickaKarna J, Kemona H, Radziwon P. Does smoking affect thrombocytopoiesis and platelet activation in women and men? Advances in Medical Science. 2006; 51: 123-6.

16. Sysmex. Automated hematology analyzer XS series. XS-1000i/XS-800i. Instruction for use. Kobe: Sysmex Corporation; 2010.

17. Sundari R, Widjaya DS, Nugraha A. Karakteristik trombosit berdasarkan jumlah trombosit, MPV, PDW, PLCR, dan PCT pada perokok aktif. Dipresentasikan pada Seminar The 1st Indonesian Conference on Tobacco on Health (ICTOH) 2014 In: Tobacco Control Support Center, editor. Proceeding The 1st Indonesian Conference on Tobacco on Health (ICTOH) 2014, Tobacco control: saves llives, saves money. Jakarta: TCSC IAKMI; 2014.

18. Kohden N. Celltac a hematology analyzer MEK-6318K. Operator's manual: Nihon Kohden; 2002.

19. Briggs C, Harrison P, Machin S. Platelet counting. In: Michelson A, ed. Platelet. $2^{\text {nd }}$ ed. Amsterdam Sydney Tokyo Singapore: Elsevier; 2007. p. $475-84$.
20. Bates I, Lewis S. Reference ranges and normal values. In: Bain B, Bates I, Laffan M, Lewis S, editors. Dacie and Lewis practical haematology. $11^{\text {th }}$ ed. London Philadelphia Toronto: Churchil Livingstone; 2012. p. 11-22.

21. Suryaatmadja M, editor. Perhimpunan Dokter Spesialis Patologi Klinik Indonesia. SI units. Tabel konversi sistem satuan SI-konvensional dan nilai rujukan dewasa-anak. Parameter Laboratorium Klinik. Jakarta Indonesia: PDS PatKlin; 2004.

22. Al-Dahr MHS. Impact of smoking on platelet, coagulation and lipid profile in young male subjects. World Applied Sciences Journal. 2010; 11(1): 118-23.

23. Miri-Moghaddam E, Mirzaei R, Arab MR, Kaikha S. The effect of water pipe smoking on hematological parameters in rats. International Journal of Hematology-Oncology and Stem Cell Research. 2014; 8(3): 37-43.

24. Calverley D, Thienelt C. Platelet function in hemostasis and thrombosis. In: Greer J, Foerster J, Lukens J, Rodgers G, Paraskevas F, Glader B, editors. Wintrobe's clinical hematology. $12^{\text {th }}$ ed. Philadelphia Sydney Tokyo: Lippincott Williams \& Wilkins; 2009. p. 490-516.

25. White J. Platelet structure. In: Michelson A, editor. Platelet. $2^{\text {nd }}$ ed. Amsterdam Sydney Tokyo Singapore: Elsevier; 2007. p. 45-74.

26. Stratmann B, Menart B, Tschoepe D. Diabetes mellitus. In: Michelson A, editor. Platelet. $2^{\text {nd }}$ ed. Amsterdam Sydney Tokyo Singapore: Elsevier; 2007. p. 697-712

27. McEver R. P-Selectin/PSGL-1 and Other interactions between platelets, leukocytes, and endothelium. In: Michelson A, editor. Platelet. $2^{\text {nd }}$ ed. Amsterdam Sydney Tokyo Singapore: Elsevier; 2007. p. 231-50.

28. Pretorius E. Ultrastructural changes in platelet membranes due to cigarette smoking. Ultrastructural Pathology. 2012; 36: 239-43.

29. Nanetti L, Vignini A, Raffaelli F, Moroni C, Silvestrini M, Provinciali L, et al. Platelet membrane fluidity and $\mathrm{Na}+/ \mathrm{K}+$ ATPase activity in acute stroke. Brain Research. 2008;1205:21-6.

30. Weinberg J. Mononuclear phagocytes. In: Greer J, Foerster J, Lukens J, Rodgers G, Paraskevas F, Glader B, ed. Wintrobe's clinical hematology. $12^{\text {th }}$ Van Demark

31. Sahu RP, Petraehe I, Van Denmark MJ, Rashid BM, Ocana JA, Tang Y, et al. Cigarette smokeexposure inhibits contactc hypersensitivity via the generation of platelete activating factor agonist. Journal of Immunology. 2013; 190 (5): 2447-54 